\title{
Investigation of Adsorbent Characteristics of Carbonized Low-Density Woods in the Treatment of Textile Effluent
}

\author{
${ }^{* 1}$ Victor O. Fatokun, ${ }^{2}$ Femi K. Owofadeju, ${ }^{1}$ Oluseyi E. Ewemoje and ${ }^{1}$ Temitayo A. Ewemoje \\ ${ }^{1}$ Department of Agricultural and Environmental Engineering, University of Ibadan, Ibadan, Nigeria \\ ${ }^{2}$ Department of Wood products Engineering, University of Ibadan, Ibadan, Nigeria \\ fatokun77@gmail.com | \{fem_fadeju | seyiajayi2\}@yahoo.com | tayo_ewemoje@yahoo.co.uk
}

Received: 31-MAR-2021; Reviewed: 23-APR-2021; Accepted: 07-MAY-2021

http://dx.doi.org/10.46792/fuoyejet.v6i2.623

\begin{abstract}
Textile industries wastewater contains pollutants which vary greatly and depend on the chemicals and treatment processes used. Toxic heavy metals in wastewater are discharged into the environment, which adversely affect human, aquatic life, and natural water bodies. This study was therefore designed to investigate adsorption of heavy metal ions (Cadmium, Zinc, Manganese, Chromium and iron) in raw textile wastewater using activated carbon from Cordia millenii and Gmelina arborea wood species. Carbon structural pattern was examined using SEM equipment. Batch sorption tests were conducted in wastewater treatment by varying absorbent contact time with the sorbate from 30 to 120 minutes (at 30minutes intervals) to facilitate attainment of equilibrium condition. The pore space diameter mean values were $9.28 \pm 1.22$ and $4.45 \pm 1.57 \mu \mathrm{m}$ for Cordia millenii Carbon (CMC) and Gmelina arborea Carbon (GAC) respectively. It was observed that over $80 \%$ Manganese removal was achieved at 120 minutes contact time for both carbons studied. Highest removal efficiencies were observed at all contact times in GAC for iron while in CMC for Chromium, Cadmium, Zinc and Manganese between 30-90minutes contact time. After 120 minutes contact time, there was insignificant difference in removal efficiency for Chromium and Manganese. However, at 30minutes contact time, percentage removal of over $60 \%$ was obtained for Manganese, implying that Manganese has high mobility towards the adsorbents surface. The activated carbons obtained from these two wood species are therefore viable options for heavy metal removal from textile effluents.
\end{abstract}

Keywords- Adsorption, activated carbon, Cordia millenii carbon, Gmelina arborea carbon, heavy metals.

\section{INTRODUCTION}

The quality of the environment is degrading on daily 1 basis as a result of increasing amount of wastes being discharged into the environment. Industrial pollution is one of the environmental problems currently facing Nigeria and a lot of efforts are being made to control it in various industries spanning length and breadth of the country to ensure that inhabitants of Nigeria live in an environment free of disease (Yusuff and Sonibare, 2004).

The textile industry is one of the important industries which releases large amount of wastewater into the environment causing the main source of water pollution which is not only harmful for aquatic life but also mutagenic to human (Mohammed et al, 2010). Textile processing employs different chemicals depending on the raw materials used, and these chemicals includes dyes, detergents, acid, soda, enzymes and salts (Aslam et al, 2004). Consequently, textile wastewater contains a large amount of various organic, inorganic dyes and various chemicals including traces of heavy metals ions (Bhardwaj et al, 2014). Muluken, (2014) noted that these textile dyes were toxic, highly stable tough to degrade and are unremoved by conventional wastewater treatment methods. Dyes present in industrial wastewater are carcinogenic, mutagenic, teratogenic and toxic (Aljeboree et al, 2014). Dyes may cause harm to children and fetus, trigger allergies and inhibiting growth at different trophic levels (Kant, 2012).

\section{${ }^{*}$ Corresponding Author}

Section A- AGRICULTURAL ENGINEERING \& BIOLOGICAL SCIENCES Can be cited as:

Fatokun V.O., Owofadeju F.K., Ewemoje O.E. and Ewemoje T.A. (2021): Investigation of Adsorbent Characteristics of Carbonized Low-Density Woods in the Treatment of Textile Effluent, FUOYE Journal of Engineering and Technology (FUOYEJET), 6(2), 1-4. http://dx.doi.org/10.46792/fuoyejet.v6i2.623
Textile industries Wastewater contains pollutants which vary in strength due to chemicals present and treatment processes. Heavy metals particularly, lead $(\mathrm{Pb})$, chromium $(\mathrm{Cr})$, cadmium $(\mathrm{Cd})$, copper $(\mathrm{Cu})$ and nickel $(\mathrm{Ni})$ are widely used for the production of color pigments of textile dyes (Bhardwaj, 2014). The discharged heavy metals into the environment can be highly toxic and can bio accumulate in the human body, aquatic animals, and natural water bodies and also in the soil (Mathur et al, 2005).

Various materials have been used as adsorbents in wastewater treatment in both industrial and domestic activities; locust bean husk (Ajayi-Banji et al, 2015), bamboo (Ijaola et al, 2013), abattoir solid waste (Sangodoyin and Ajayi-Banji, 2013), cassava peel (Omotosho and Ewemoje, 2020), snail shells (Bolade and Sangodoyin, 2018), wood (Yargicoglu et al, 2015), Thevetia peruviana (Baseri et al, 2012). Therefore, this study was designed to develop a low-cost adsorbent from Cordia millenii and Gmelina arborea wood species in order to determine the most efficient in heavy metals sequestration from textile wastewater.

\section{Materials ANd Method}

\subsection{Preparation of Activated Carbon from the TWO WOOD SPECIES}

The two wood species (Cordia millenii and Gmelina arborea) used for the study were purchased and circular saw was used to chop the woods into smaller pieces at Oke-Ado Sawmill in Ibadan, Oyo State, and bagged independently in sacks. The woods were identified at the herbarium unit of Forestry Research Institute of Nigeria (FRIN). The two wood species were washed with tap water to remove dirt and other contaminants that might adhere to the material. The washed woods were dried in open air and intense sunlight for one week to reduce the moisture content. Dried woods were weighed and pyrolyzed at $500^{\circ} \mathrm{C}$ for 
$120 \mathrm{~min}$ in a bioreactor at Forestry Research Institute of Nigeria (FRIN). The biochar was crushed with mortar and pestle for size reduction and sieved into $1.18 \mathrm{~mm}$ size and thereafter stored. Two hundred grams of the carbonised samples from the two wood species were munificently washed with distilled water, filtered and then oven-dried at $120^{\circ} \mathrm{C}$ for 12 hours. Both chars were then impregnated with zinc chloride salt based on a mass ratio suggested by Das et al., (2015); 100\% (activating agent/precursor), $100 \mathrm{~g}$ of dried precursor carbon was well mixed with $600 \mathrm{ml}$ of concentrated solution of $\mathrm{ZnCl}_{2}$ that contains $100 \mathrm{~g}$ of $\mathrm{ZnCl}_{2}$. The slurries formed from the impregnation were kept for 24hours for proper soaking of $\mathrm{ZnCl}_{2}$ on its surface. The slurry was kept inside the oven at $102 \pm 3^{\circ} \mathrm{C}$ for 24 hours. The filtrates (char) were washed with distilled water and oven dried for $12 \mathrm{hrs}$ at $120^{\circ} \mathrm{C}$ and stored in air-tight jar for further studies (Bolade and Sangodoyin, 2018). Chars structure were investigated using SEM machine.

\subsection{WAstewater Collection}

The textile wastewater was obtained from Itoku textile dyeing industry, Abeokuta South Local Government Area of Ogun State, Nigeria. Grab sampling method was the mode of wastewater collection which was collected in 5L sterilized container, properly washed with distilled water and allowed to dry. The container was rinsed thoroughly with wastewater before filling to the brim and firmly capped. The wastewater was temporarily refrigerated at $5^{\circ} \mathrm{C}$ for $17 \mathrm{hrs}$ to prevent biodegradation.

\subsection{ADSORPTION EXPERIMENTS}

A batch study was conducted on wastewater at natural $\mathrm{pH}$ of effluent $(3.81)$ at $27^{\circ} \mathrm{C}$ which is the room temperature to be representative of environmentally relevant conditions (Desta, 2014). A 200ml of wastewater had six grams of adsorbents inserted. The wastewater samples were agitated intermittently, allowing sufficient time for adsorption equilibrium. It was assumed that the applied shaking speed allows all the surface area of the adsorbents to come in contact with the ions in the wastewater over the course of the experiments (Desta, 2014). The contact time was varied from 30 to $120 \mathrm{~min}$ (at $30 \mathrm{~min}$ interval) to determine the optimum time the adsorbent will treat the wastewater. Thereafter, the wastewater was filtered through (Whatmann No. 44) filter paper. Samples of treated effluent were taken after 30, 60, 90 and 120mins.

Adsorbent removal efficiency is a measure in percentage of the amount of adsorbate adsorbed from a given solution. Removal efficiency of the adsorbents were calculated using the following equations:

$$
\text { Removal efficiency }=\frac{(C i-C e)}{C i} \times 100
$$

Where $\mathrm{C}_{\mathrm{i}}$ and $\mathrm{Ce}(\mathrm{mg} / \mathrm{l})$ represents initial and after treatment concentrations respectively.

\subsection{Analytical Procedures}

Heavy metals investigated before and after treatment according to standard methods for the examination of water and wastewaters (APHA, 1998) were iron, chromium, cadmium, zinc and manganese. The experiments were replicated trice representative and reproducible results.

\section{RESULTS AND DISCUSSION 3.1 Activated Carbon Characterization}

The $\mathrm{pH}$ value of non-activated Cordia milleni carbon (CMC) and Gmelina arborea carbon (GAC) were 9.82 and 9.62 respectively indicating that the solutions of both chars are weakly alkaline. After activation with zinc chloride and further washing with distilled water, the $\mathrm{pH}$ of both chars were 6.75 and 6.8 respectively which are light acidity. From Fig. 1, pores chars were interconnected with $\mathrm{CMC}$ having larger pore space diameter of mean diameter size of $9.28 \pm 1.22 \mu \mathrm{m}$ and while GAC pore space diameter mean value was $4.45 \pm 1.57 \mu \mathrm{m}$.
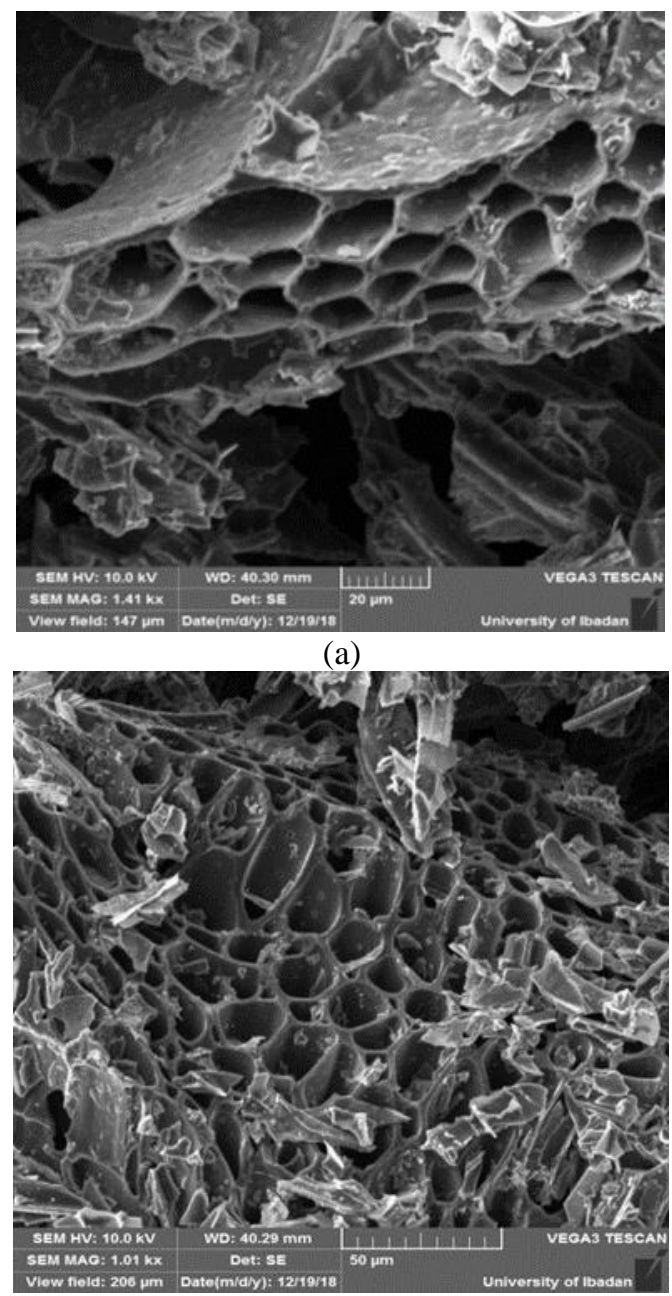

(b)

Fig. 1: Scanning Electron Microscope of (a) Cordia millenii Carbon (b) Gmelina arborea Carbon

\subsection{Heavy Metals Removal Efficiency}

High removal efficiency of $89.38 \%$ and 79.86 for manganese and cadmium at $120 \mathrm{mins}$ contact time for CMC while GAC has higher removal efficiency of $76.64 \%$ and $89.38 \%$ for iron and manganese respectively at 120mins contact time (Fig. 2). Manganese demonstrated exceptionally rapid uptake at 30mins contact time for both activated carbon, this is in agreement with the findings of Ajayi-Banji et al, (2015). This shows that manganese have high mobility to the adsorbents surface. The general trend for each adsorbents and heavy metal 
studied shows contact time influence removal efficiency throughout the period of the experiment though the adsorbents displayed different sorption tendencies with respect to heavy metals (Fig. 3).

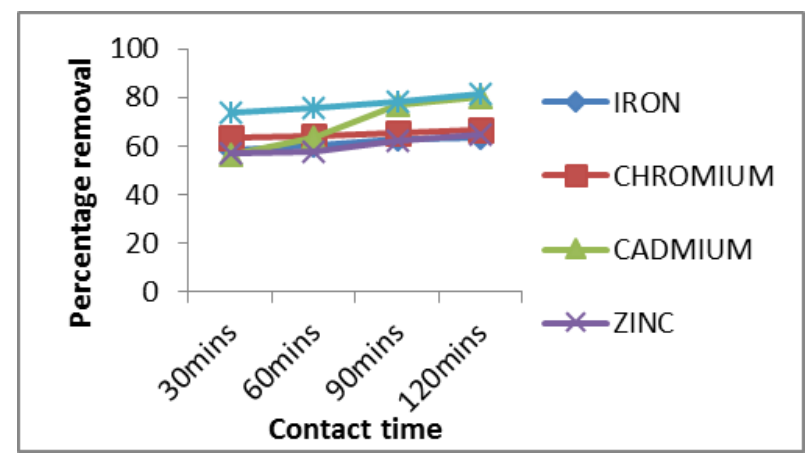

Fig. 2: Heavy metals removal using activated Cordia millenii Carbon (CMC)

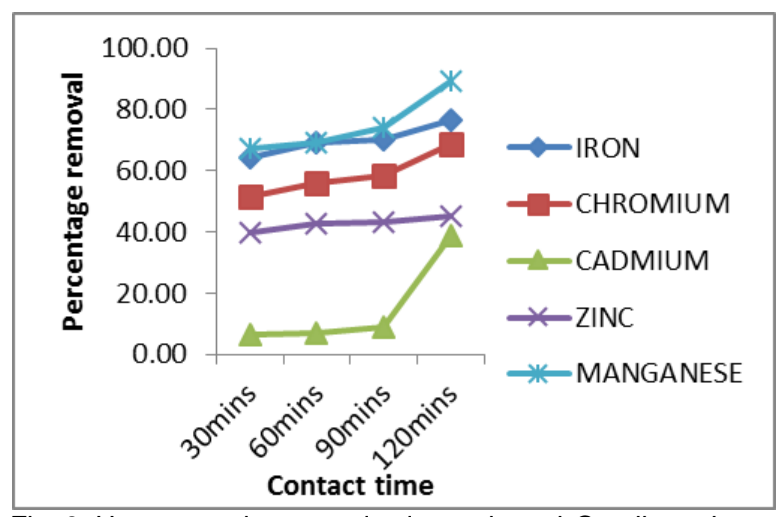

Fig. 3: Heavy metals removal using activated Gmelina arborea Carbon (GAC)

It was observed that cadmium and zinc require more contact time before complete adsorption is achieved. Similar observation was suggested by Sangodoyin and Ajayi-Banji (2013). In comparing the two absorbents used, activated CMC percentage removal of the heavy metals ranged approximately $56-82 \%$ while percentage removal using activated GAC ranged approximately $76-89 \%$. The observed indicated a general better percentage heavy metals removal using activated $\mathrm{CMC}$ with larger pore space mean diameter size of $9.28 \pm 1.22 \mu \mathrm{m}$ than activated GAC with smaller pore space mean diameter value of $4.45 \pm 1.57 \mu \mathrm{m}$. It can be deduced from the Fig. 2 and 3 that for all contact times, activated CMC removal of zinc, cadmium and chromium performed better than the activated GAC. Hence, better removal of zinc, cadmium and chromium may be due to larger pore space mean diameter which is an indication of increased surface area of the activated carbon material.

From Fig. 4, GAC has the highest removal efficiency for iron at all contact time indicating that activated carbon with smaller pore spaces are more efficient for iron removal. The $\mathrm{CMC}$ has highest removal efficiency for chromium, cadmium, zinc and manganese between 3090 mins contact time but at 120 mins contact time there is slight difference in removal efficiency between the two carbons for chromium and manganese.

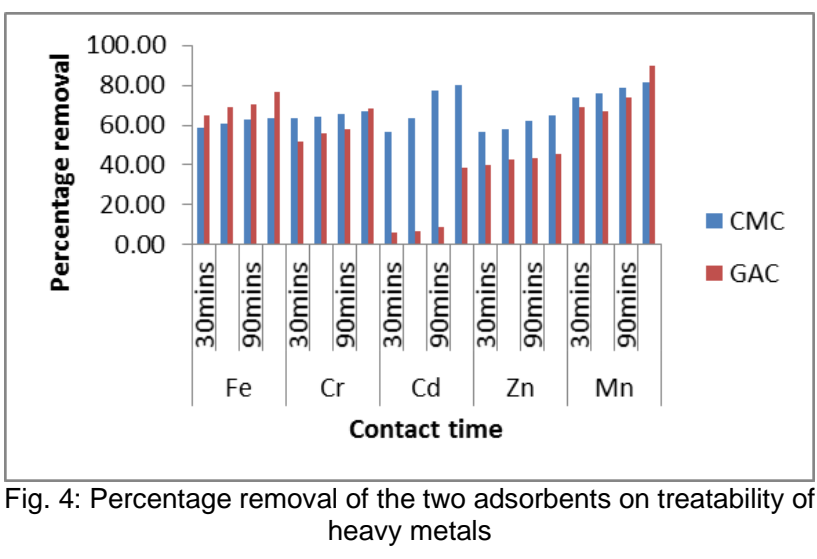

\section{ConCLUSION}

The study shows that CMC carbon has strong affinity for cadmium, zinc and magnesium at all contact time except at 120mins where GAC has higher removal efficiency for manganese from textile wastewater in batch column experiment. Removal efficiency at 120 mins contact time was greater than $60 \%$ for both carbon except cadmium and zinc for GAC. Removal efficiencies on both adsorbents depend on contact time, heavy metal involved and the pore sizes of the adsorbents. The activated carbon derived from the two wood species proved useful and effective in detoxifying heavy metals in textile wastewater.

\section{REFERENCES}

Ajayi-Banji A.A., Ewemoje T.A. and Ajimo A.A. (2015). Efficacy of locust beans husk char in heavy metal sequestration. Environmental research, engineering and management, 71(4), pp 5-10.

Aljeboree A.M., Alshirifi A.N., and Alkaim A.F. (2014). Kinetics and equilibrium study for the adsorption of textile dyes on coconut shell activated carbon, Arabian Journal of Chemistry.

APHA (1998). Standard Methods for the Examination of Water and Wastewater 20th Ed. American Public Health Association Washington, DC.

Aslam, M.M., Baig, M.A., Hassan, I., Qazi, I.A., Malik M., Saeed H. (2004). Textile wastewater characterization and reduction of its COD \& BOD by oxidation. Electronic journal of environmental, agricultural and food chemistry 3, 804-811.

Baseri J.R., Palanisamy P.N., and Kumar P.S. (2012). Adsorption of basic dyes from synthetic textile effluent by activated carbon prepared from Thevetiaperuviana. Indian journal of chemical technology, vol 19, pp 311-321.

Bhardwaj V., Kumar P. and Singhal G. (2014). Toxicity of heavy metals pollutants in textile mills effluents. International journals of scientific \& engineering research, vol 5(7), pp 664-666.

Bolade O.O. and Sangodoyin A.Y. (2018). Adsorption and Equilibrium Studies of Textile Effluent Treatment with Activated Snail Shell Carbon. IOSR Journal of Environmental science, Toxicology and Food Technology. Vol 12, issue 4, pp 26-33.

Das D., Samal D.P. andMelkap B.C. (2015). Preparation of activated carbon from green coconut shell and its characterization. Journal of chemical engineering and process technology 6: 248. Doi: 10.4172/2157-7048.1000248

Desta, M. B. (2014). Batch adsorption experiments: Langmuir and freundlich isotherm studies for the adsorption of textile metal ions 
onto Teff straw (Eragrostistef) agricultural waste. Journal of thermodynamics, volume 2013, article ID375830.

Ijaola O.O., Ogedengbe K., and Sangodoyin A.Y. (2013). On the efficacy of activated carbon derived from bamboo in the adsorption of water contaminants. International Journal of Engineering Inventions, vol 2(4), pp 29-34.

Kant, R. (2012). Textile dyeing industry and environmental hazard, Natural Science, 4(1), 12-26.

Mathur, N., Bhatnagar, P. and Bakre, P. (2005). Assessing mutagenicity of textile dyes from pali (Rajasthan) using ames bioassay. Applied Ecology and Environmental Research, pp 111118.

Mohammed A.R., Mohammadi M. and Darzi G.N. (2010). Preparation of carbon molecular sieve from lignocellulosic biomass: A review. Renewable and sustainable energy reviews. Vol 14(6); 1591-1599.

Muluken M.F. (2014). Heavy metal concentration in effluents of textile industry, TikurWuha River and milk of cows watering on this water source, Hawassa, Southern Ethiopia. Research journal of environmental sciences, 8:422-434.

Omotosho O.A. and Ewemoje, T. A. (2020). Sequential peroxideoxidation and adsorption treatment of cassava processing wastewater: prospects and limitations in augmentation of water budgeting practices . Open Journals of Environmental Research vol 1 (1), pp 47-58.

Sangodoyin A.Y. and Ajayi-Banji A.A. (2013). Utilization of abattoir solid wastes as biosorbents for surface water treatment. International Journal of Engineering Inventions, vol 2(11), pp 4247.

Yargicoglu E.N., Sadasivam B.Y., Krishna R.R. and Spokas K. (2015). Physical And chemical characterization of waste wood derived biochar. Elsevier, waste management 36(2015) 256-268.

Yusuff R.O. and Sonibare J.A. (2004). Characterization of textile industries' effluents in Kaduna, Nigeria and pollution implications. Global nest: the int. J. Vol 6, no 3, pp 212-221. 